\title{
Membrane Stability during Biopreservation of Blood Cells
}

\author{
Christoph Stoll Willem F. Wolkers \\ Institute of Multiphase Processes, Leibniz Universität Hannover, Germany
}

\section{Keywords}

Biopreservation - Storage - Erythrocyte .

Thrombocyte · Cryopreservation - Lyophilization .

Freeze-drying $\cdot$ Membrane $\cdot$ Red blood cell .

Platelet

\section{Summary}

Storage methods, which can be taken into consideration for red blood cells and platelets, include liquid storage, cryopreservation and freeze-drying. Red blood cells can be hypothermically stored at refrigerated temperatures, whereas platelets are chilling sensitive and therefore cannot be stored at temperatures below $20^{\circ} \mathrm{C}$. Here we give an overview of available cryopreservation and freeze-drying procedures for blood cells and discuss the effects of these procedures on cells, particularly on cellular membranes. Cryopreservation and freeze-drying may result in chemical and structural modifications of cellular membranes. Membranes undergo phase and permeability changes during freezing and drying. Cryo- and lyoprotective agents prevent membrane damage by different mechanisms. Cryoprotective agents are preferentially excluded from membrane surfaces. They decrease the activation energy for water transport during freezing and control the rate of cellular dehydration. Lyoprotectants are thought to stabilize membranes during drying by forming direct hydrogen bonding interactions with phospholipid head groups. In addition, lyoprotectants can form a glassy state at room temperature. Recently liposomes have been investigated to stabilize blood cells during freezing and freeze-drying. Liposomes modify the composition of cellular membranes by lipid and cholesterol transfer, which can stabilize or destabilize the low temperature response of cells.

\author{
Schlüsselwörter \\ Biologische Konservierung · Lagerung · Erythrozyt · \\ Thrombozyt · Kryokonservierung · Lyophilisierung · \\ Gefriertrocknung · Membran · Rote Blutkörperchen · \\ Blutplättchen
}

\section{Zusammenfassung}

Theoretisch existieren drei Methoden zur Lagerung roter Blutkörperchen und Blutplättchen: in der flüssigen Phase, eingefroren oder gefriergetrocknet. Rote Blutkörperchen können gekühlt bei etwa $4{ }^{\circ} \mathrm{C}$ gelagert werden, wobei Blutplättchen empfindlich gegenüber Abkühlung sind und nicht kälter als bei Raumtemperatur aufbewahrt werden dürfen. Diese Übersichtsarbeit befasst sich mit den gegenwärtig bekannten Prozeduren zur Kryokonservierung und Gefriertrocknung von Blutzellen, außerdem wird die Auswirkung dieser Prozesse auf die Zellen und insbesondere deren Membranen diskutiert. Sowohl die Kryokonservierung als auch die Gefriertrocknung können zu chemischen und strukturellen Veränderungen in Zellmembranen führen. Außerdem kann es zu Phasenwechseln und Permeabilitätsänderungen während des Einfrierens und Trocknens kommen. Kryo- und Lyoprotektiva schützen Zellmembranen aufgrund unterschiedlicher Wirkmechanismen, wobei Kryoprotektiva bevorzugt von der Zelloberfläche ausgeschlossen werden. Sie senken die Aktivierungsenergie für Wassertransport während des Einfrierens und Kontrollieren den Grad der Wasserabgabe der Zellen. Bei Lyoprotektiva hingegen wird davon ausgegangen, dass sie während des Trocknungsvorgangs Wasserstoffbrücken mit den Kopfgruppen der Phospholipide in der Membran bilden. Außerdem können Lyoprotektiva schon bei Raumtemperatur vitrifizieren. Vor kurzem wurde auch die Einwirkung von Liposomen auf rote Blutkörperchen während des Einfrierens und des Gefriertrocknens untersucht. Liposomen modifizieren die Zusammensetzung der Zellmembran durch Transfer von Lipiden und Cholesterin, was die Reaktion der Zellen auf niedrige Temperaturen verändern kann.

\begin{tabular}{ll}
\hline KARGER & ๑ 2011 S. Karger GmbH, Freiburg \\
Fax +497614520714 & Accessible online at: \\
Information@Karger.de & www.karger.com/tmh \\
www.karger.com &
\end{tabular}

Dr. Willem F. Wolkers

Institute of Multiphase Processes, Leibniz Universität Hannover

Callinstraße 36, 30167 Hannover, Germany

Tel. +49 511762 193-53, Fax -89

wolkers@imp.uni-hannover.de 


\section{Introduction}

Proper storage of blood cells still poses major problems in blood banks. Long-term storage of these blood cells is crucial to ensure permanent availability for clinical use. Blood transfusions are used for trauma victims, surgery, organ transplants and patients receiving treatment for leukemia, cancer or other diseases such as sickle cell disease and thalassemia. Due to a steadily increasing demand of blood products, there is a need to improve currently applied storage methods to avoid shortages. The main blood cell products are concentrates of red blood cells (RBCs) and platelets. Storage methods for blood cells include liquid storage and may include cryopreservation. So far, freeze-drying is not applicable in the case of any blood component where viable cells are needed for patient treatment. RBCs are stored hypothermically at temperatures in the range of $2-6{ }^{\circ} \mathrm{C}$. Platelets are chilling sensitive and therefore cannot be stored at lower temperatures: They need to be stored at least at ambient temperatures to avoid chilling injury. Cryopreservation does in certain cases and freeze-drying may provide alternative storage methods, however, there is always the danger that they damage cellular structures. Membranes are considered as the primary site of biopreservation injury. In the following, we provide an overview on biopreservation-related stress factors on blood cell membranes, mechanisms of membrane stabilization and recent advances in biopreservation of blood cells using membrane modification strategies.

\section{Mechanisms of Injury during Biopreservation}

\section{Damage by Hypothermic Storage}

\section{$R B C s$}

In Germany (and other European countries) erythrocytes can be stored at $2-6{ }^{\circ} \mathrm{C}$ for up to 42 (or 49) days in additive solutions such as SAG-M (or PAGGS-M). With increasing storage time, however, blood cell quality decreases, commonly accepted measures are lower ATP and 2,3-DPG levels [1]. Since metabolic processes at temperatures around $4{ }^{\circ} \mathrm{C}$ are only slowed down and not completely suppressed, they are one of the main causes of storage injury. RBCs show a decrease in deformability and a change in shape from normal smooth discoid to an echinocyte shape or spheroid shape with specula. These changes are initially reversible, but become irreversible after prolonged storage. The shedding of microvesicles is also considered as a sign of aging during storage. These phospholipid- and cholesterol-rich vesicles of less than $500 \mu \mathrm{m}$ segregate from stored RBCs over time, but their function is largely unknown. It has been speculated that this is a way for the cells to get rid of deleterious compounds [2-4]. The effects of storage are particularly visible at the membrane level. Membrane alterations during storage of RBCs include flip-flop of phosphatidyl serines, which relocate from the inner membrane leaflet to the outer membrane leaflet. An increased phosphatidyl serine concentration in the outer membrane leaflet is thought to mediate RBC clearance by macrophages [1]. Membrane damage during storage is also caused by accumulation of lipid peroxidation products, which decrease membrane integrity and cause hemolysis [5]. Hypothermic storage causes reorganization of the membrane microstructure, e.g. the reorganization of lipid raft proteins such as stomatin and flotillins or accumulation of membrane proteins damaged by oxidation throughout storage $[6,7]$.

\section{Platelets}

Storage of platelets is a major problem in blood banks because cooling of platelets below $20{ }^{\circ} \mathrm{C}$ causes cold-induced activation. Platelets are activated by refrigeration and can only be stored at temperatures of at least $20{ }^{\circ} \mathrm{C}$. Activated platelets are rapidly taken out of circulation in a transfusion recipient [8, 9]. Moreover, storage of platelets at ambient temperatures allows for the possibility of bacterial growth, and this can have fatal consequences for a recipient. Cold shock damage in platelets and other cells has been linked to lipid phase transitions that cause the membrane to become transiently leaky $[10,11]$. Cooling alters the phase state and structural organization of membrane components, leading to coalescence of lipid rafts in membranes, events that appear to be irreversible on warming [12]. Platelets exhibit two phase transition temperatures between 0 and $45^{\circ} \mathrm{C}$. The main lipid phase transition between $10-20^{\circ} \mathrm{C}$ coincides with increases in $\mathrm{Ca}^{2+}$ fluxes and morphological changes [13]. A second, smaller phase transition at around $30{ }^{\circ} \mathrm{C}$ is thought to arise from the melting of lipid rafts [12]. Under physiological conditions, membranes are thought to be in the fluid state. Cooling causes lateral phase separation of membrane components to the point of macroscopic visible rafts. Rafts are thought as cell signaling platforms, which in case of platelets mimic thrombin induced activation [14]. When platelets are stored for longer than $24 \mathrm{~h}$ at $4{ }^{\circ} \mathrm{C}$, cooling-induced changes in membrane structure become irreversible and activation takes place. Liquid stored platelets at $22{ }^{\circ} \mathrm{C}$ have a mandated shelflife of 4 days in Germany. Coalescence of lipid rafts is not observed in RBCs [15]. This is likely due to the relatively high membrane cholesterol content of RBCs preventing coalescence of rafts.

\section{Cryodamage}

The major stresses on membranes during cryopreservation are fusion- and freezing-induced membrane phase transitions which can lead to an increase in permeability and lateral phase separation of specific phospholipid classes, cholesterol or proteins [16]. The main driving force for phase separation 
is the hydrophobic mismatch between membrane components such as lipids with different acyl chain length or between lipids and proteins. The greater the differences in thickness, the more hydrophobic residues are exposed to water. During cooling lipids undergo fluid-to-gel phase transitions, which cause a thickening of lipid bilayers, due to straightening of disordered acyl chains. By cooling the fraction of lipids in the fluid state decreases or disappears, thus the hydrophobic mismatch between the different species diminishes, too. As a result, specialized membrane domains (rafts) dissipate during cooling [17]. Membranes are exposed to severe dehydration

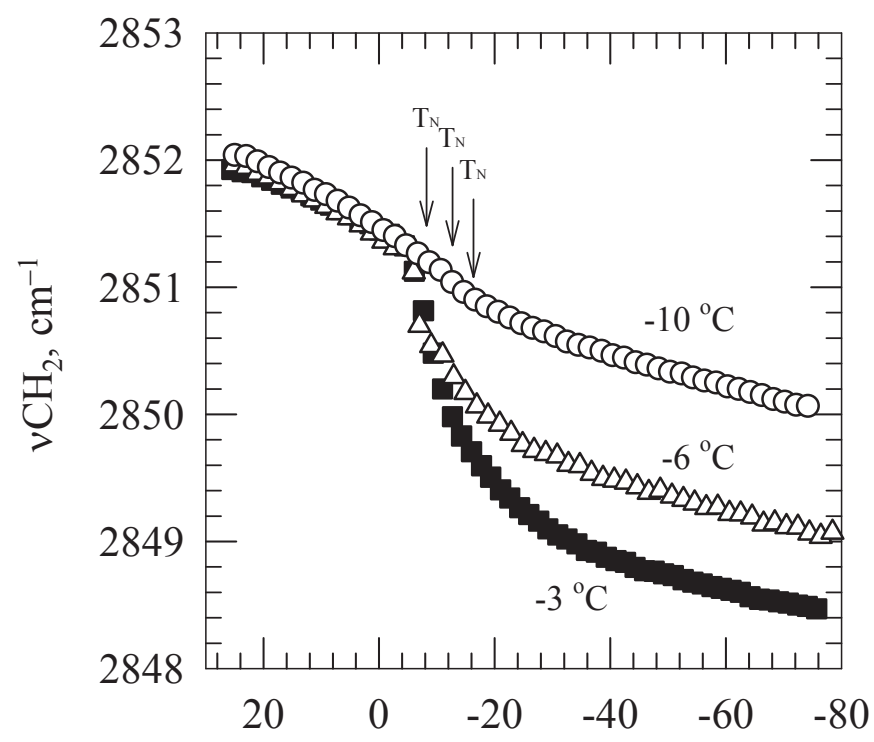

Temperature, ${ }^{\circ} \mathrm{C}$

Fig. 1. Membrane phase behavior of $\mathrm{LNCaP}$ tumor cells during cooling and nucleation at various sub-zero temperatures. The data points reflect $v \mathrm{CH}_{2}$ during freezing the cells down to $-80^{\circ} \mathrm{C}$. Samples were nucleated at $-3{ }^{\circ} \mathrm{C}$ (filled squares), $-6{ }^{\circ} \mathrm{C}$ (open triangles) or at $-10{ }^{\circ} \mathrm{C}$ (open circles). Data are adapted from [18]. during freezing. Freezing causes removal of the bound water around the phospholipid head groups, resulting in lyotropic phase transitions [18]. Freezing-induced phase transitions are usually stronger and more cooperative compared to those at supra-zero temperatures [19].

One key membrane property determining the faith of a cell after freezing and thawing is the membrane permeability to water. The cell-specific membrane hydraulic permeability determines the optimal cooling rate needed to minimize cryopreservation damage. For cells undergoing freezing, a twofactor hypothesis of damage has been developed [for review see 20]. At high cooling rates, cell losses are associated with intracellular ice formation. For cells cooled slowly, damage is described as 'solution effects injury', which is related to cellular dehydration. Typically, there is a critical cooling rate for maximum survival. This cooling rate, however, varies greatly depending upon the cell type and is related to the cell-specific membrane permeability to water [21-23]. Freezing causes fluid-to-gel phase transitions affecting the membrane hydraulic permeability and the activation energy for water transport. Figure 1 shows the effects of the ice nucleation temperature on membrane phase behavior: high sub-zero nucleation temperatures (dehydrating freezing conditions) cause strong fluid-to-gel phase transitions. Figure 2 illustrates the effect of different cooling conditions on cells and on membrane phase state. Dehydrating freezing conditions cause fluid-to-gel phase transitions, whereas conditions resulting in intracellular ice formation leave the membranes in a relatively fluid state. The freezing-induced effects on membrane phase state also affect the cell's membrane permeability to water at sub-zero temperatures. The membrane hydraulic permeability at subzero temperatures differs substantially from the one above the freezing point [24]. RBCs are extremely permeable to water, and hence the optimal cooling rate is extremely high at approximately $2,500 \mathrm{~K} / \mathrm{min}$ [25], which can hardly be reached in the sample volumes as required for therapeutically usable blood.

\section{slow freezing (high nucleation)}

Fig. 2. Schematic representation illustrating the effects of freezing on cells and cellular membranes. The small grey filled circles represent water and the star shaped asterisks represent ice crystals. Slow freezing and high sub zero nucleation result in cellular dehydration and gel phase formation in membranes. Fast freezing and low ice nucleation temperatures (supercooling) result in intracellular ice formation. Membranes remain relatively hydrated and the residual conformational disorder of membranes is greater compared to dehydrated cells. This figure is adapted from [71].
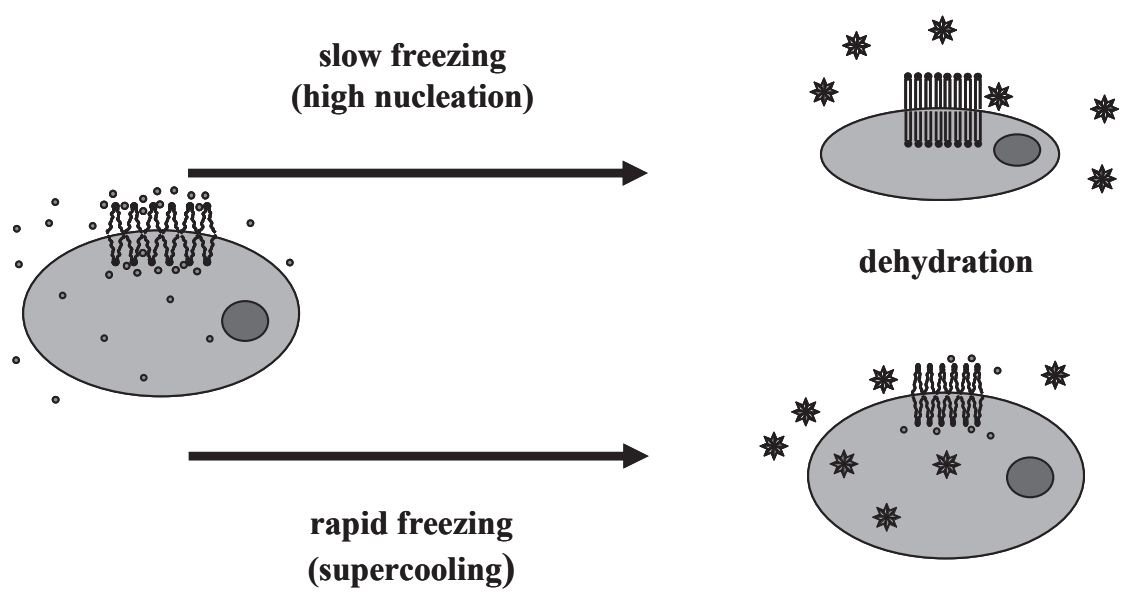

intracellular ice formation (IIF) 
Fig. 3. Schematic representation illustrating the physical and chemical effects of freezing and drying on membrane lipid phase state, membrane organization, and chemical lipid stability. The simplified membrane is composed of lipids, cholesterol and transmembrane proteins. Damaging events occurring during freezing and desiccation include gel phase formation, reorganization of cholesterol, protein aggregation, and accumulation of free fatty acids.
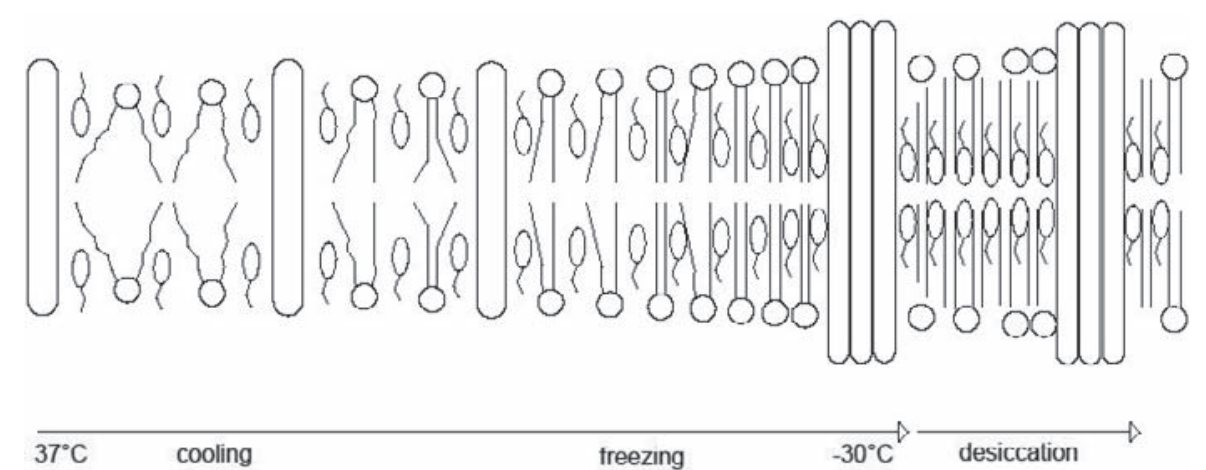

\section{Freeze-Drying Damage}

Intuitively freeze-drying seems to be one of the most attractive methods for blood cell storage, and the ultimate goal is storage in the dried state at room temperature. From what we know today, freeze-drying, however, is also more damaging to macromolecular and cellular structures compared to freezing. For lyophilization a sample is first frozen to crystallize the solvent (water) and to separate it from the solutes. Subsequently the solvent content is reduced by sublimation and desorption to levels that are known to strongly reduce chemical reactions [26]. Thus, the process of freeze-drying contains two different steps that may be harmful for cells: a freezing step followed by a drying step. Although freezing and drying are different stress factors, there are similarities between the two processes [16]. The removal of intracellular water causes drastic changes in inter- and intramolecular interactions. Upon drying, intracellular proteins and membranes compensate the loss of hydrogen bonding with water by forming hydrogen bonds with other molecules. This results in forced intermolecular interactions between molecules that normally would not interact with each other in the presence of bulk water, but will do so upon dehydration. In proteins, the loss of hydrogen bonds with water can be compensated by protein-protein interactions and may thus lead to protein aggregation or denaturation [27-29]. Dehydration-induced protein-protein interactions can lead to irreversible conformational changes and, in enzymes, to a loss of enzymatic activity [30]. In membranes, water loss from the phospholipid head groups may lead to phase transitions from the biologically active fluid phase to the gel phase [31, 32]. In addition, freezing and drying result in accumulation of reactive oxygen species causing chemical modifications including formation of free fatty acids. The effects of freezing and drying on membranes are illustrated in figure 3. A small fraction of nonfreezable water usually remains with the phospholipid head groups. When this water fraction is removed by drying in absence of lyoprotectiva, membrane injury occurs by fusion with other membranes.

\section{Membrane Stabilization during Cryopreservation and Freeze-Drying}

\section{Cryopreservation}

There are several theories that describe how cryoprotective agents protect membranes and proteins in cells during freezing stress. The preferential exclusion theory $[33,34]$ is based on the observation that molecules such as compatible solutes are excluded from protein surfaces, which leads to a state of preferential hydration for the protein surface. Compatible solutes are small organic osmolytes including sugars, polyols, amino acids, and derivatives thereof that are compatible with cell metabolism even at molar concentrations [35]. A considerable number of these compatible solutes possesses cryoprotective properties. Stabilization of proteins (and cell membranes) during freezing requires a co-solute that is preferentially excluded from the protein surface $[16,36]$. The solute's exclusion from the surface of the protein is thermodynamically unfavorable, since it results in a decrease in entropy of the system. A protein in its native conformation exposes the smallest surface area and is thus the thermodynamically most favorable state. Preferential exclusion increases the energy barrier for protein denaturation [16]. A preferential binding solute will destabilize a protein since energy is released upon binding of the solute with the protein, which promotes unfolding of the protein. Nearly all known stabilizing solutes are excluded from protein surfaces. Studies on the effect of compatible solutes on membrane systems suggest that compatible solutes are also preferentially excluded from the membranesolvent interface [37].

Recent studies have demonstrated how cryoprotective agents such as glycerol or dimethyl sulphoxide (DMSO) affect sub-zero membrane phase behavior and membrane hydraulic permeability parameters of mammalian cells [24, 38]. Interestingly, freezing-induced membrane phase changes are not prevented in the presence of cryoprotective additives (CPA) but they occur more gradual over a wider temperature regime. CPAs decrease the activation energy for water transport during freezing, particularly the transport of membrane-bound 


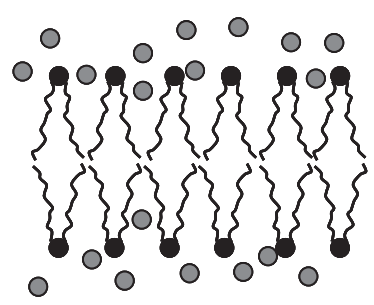

hydrated bilayer (liquid-crystalline phase)
Fig. 4. Schematic representation illustrating the effects of drying on lipid conformation in the dried state. The grey filled circles represent water and the grey filled squares represent sucrose. Drying in the absence of a protectant (sucrose) results in a liquid crystalline to gel phase transition during dehydration and vice versa during rehydration. The liquid crystalline phase is maintained during drying (and rehydration) in presence of a protectant. This idea has been postulated as the water replacement hypothesis [31, 32].

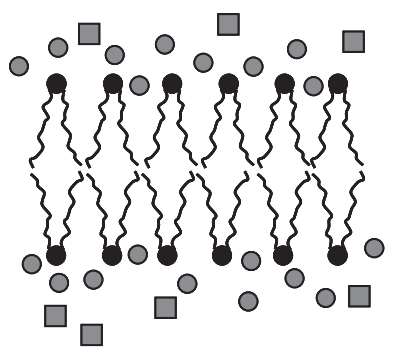

hydrated bilayer, sucrose (liquid-crystalline phase)

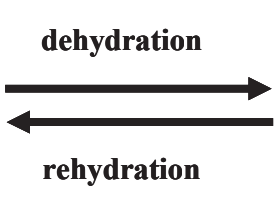

dried bilayer, water removed

(gel phase)
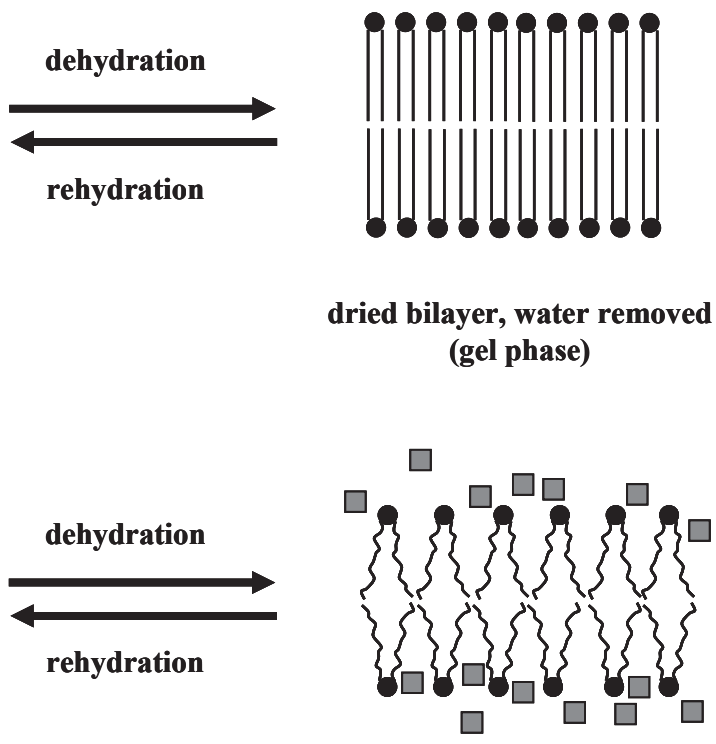

water replaced with sucrose (liquid-crystalline phase) water [24]. These effects of CPAs on membrane hydraulic permeability parameters have some important practical applications as they result in a decrease of the optimal cooling rate for cryopreservation to technically more easily achievable rates. RBCs, for example, require extremely high cooling rates in the absence of cryoprotective agents [25]. In the presence of $40 \%$ glycerol, however, slow cooling rates can be used to obtain maximum survival after freezing and thawing [39].

Other protective mechanisms of CPAs include their effects on ice crystallization and formation of a glassy state. A freezeconcentrated solution pass into a highly viscous glassy state at a characteristic glass transition temperature, immobilizing the product and thus preventing degradation reactions. Iijima [40] has conducted a study using differential scanning calorimetry (DSC) on the thermal behavior of glycerol-water solutions (binary system) and the more complex glycerol-based cryoprotective solutions that are used clinically for cryopreservation of RBCs.

\section{Freeze-Drying}

In contrast to freezing, the requirements for solute specificity are more stringent in the case of drying; only certain sugars are effective and stabilization requires direct interaction between the sugar and polar residues in the protein or phospholipid [16]. The preferential exclusion model is valid for the more diluted range of solute concentrations and therefore cannot be extrapolated to dried systems. The two central hypotheses proposed for sugar-biomolecule interactions in the dried state are the water replacement hypothesis and the water entrapment hypothesis. The water replacement theory proposed by Crowe and co-workers [reviewed in 17] is based on their studies on anhydrobiotic organisms which are able to loose almost all of their cellular water but are nevertheless able to return to full activity after rehydration. Protection is assigned to certain compatible solutes, particularly nonreducing disaccharides, and their direct interactions with membranes and proteins. In this model, the hydrogen bonding interactions which are provided by water in the hydrated state are replaced in the dried state by these solutes (fig. 4). On the other hand, the water entrapment hypothesis postulates that, in the dry state, sugars rather than direct binding to biomolecules entrap the residual water at the interface with the biomolecule [41, 42]. In this model, a critical amount of bound water around macromolecular structures is considered to be necessary for protection in the dried state. In a recent study, we have shown that water entrapment rather than water replacement explains the effect of trehalose on lipid phase behavior of lipid bilayers during the initial phase of drying [43].

Moreover, in order to achieve stability of a freeze-dried formulation at ambient temperatures, the formulation needs to be in a glassy state. Due to the extremely high viscosity of the vitreous state, the rate of deleterious reactions would be very low, since most physical and chemical processes are diffusion-limited. Thus, transition in the glassy state results in immobilization of cellular structures and biochemical components, which preserves their biological function [44]. The reason why disaccharides are used instead of monosaccharides in freeze-drying protocols is related to the difference regarding the glass transition temperature. The glass transition temperature of a formulation based on monosaccharides is lower 
compared to one based on disaccharides [45]. Moreover, freeze-dried formulations based on reducing monosaccharides are chemically unstable due to Amadori and Maillard reactions [46].

\section{Recent Advances in Biopreservation of Blood Cells}

\section{Cryopreservation}

The driving force for the development of cryopreservation methods for RBCs differs from that of platelets. RBCs are quite stable over a rather long (i.e. weeks) hypothermic storage period. Cell quality, however, decreases during storage. In addition, liquid storage has always been a problem in the case of extremely rare blood groups, especially in the case of already existing antibodies. For platelets, cryopreservation seems to be even more attractive, as platelets can be stored unfrozen only for a very limited time period (days)

Cryopreservation procedures for RBCs have been developed in the beginning of the second half of the last century. Techniques using glycerol as cryoprotective agent either need a high glycerol content (40\%) combined with a low cooling rate, or a low glycerol content (17-20\%) in combination with a high cooling rate is required $[39,47]$. The main disadvantage of these procedures is the subsequent deglycerolization process required after thawing. RBCs which contain more than $2 \%$ glycerol lyse in an isotonic medium (such as circulating blood plasma) medium due to osmotic stress. The deglycerolization process is also difficult to handle when trying to maintain sterile conditions (which is highly important when the washed units are not directly transfused). An option to circumvent post-thaw washing procedures is the application of nontoxic high-molecular-weight extracellular additives. For the cryopreservation of RBCs polyvinylpyrolidone (PVP) and hydroxyethyl starch (HES) have been applied. Especially the latter has received some attention in transfusion medicine. Additives like HES and PVP do not penetrate the cell membrane, but the protective mechanisms of these molecules are not yet completely understood. They affect the kinetics of ice nucleation and crystal growth; both are good glass formers, and because of their considerable colligative properties at high concentrations they may cause dehydration of the cell. Freezing of RBCs in the presence of $11.5 \% \mathrm{w} / \mathrm{w}$ HES yields over $90 \%$ viable cells after thawing in terms of saline stability [48]. It has been demonstrated in a systematical clinical study with autologous RBCs that at least one unit of frozen/thawed packed RBCs could be re-infused without any post-thaw washing step [49]. The main advantage of HES over PVP is that it is quickly removed from the organism and that HES (in contrast to PVP) is a biodegradable compound which is eliminated from the circulation [50]. However, despite of existing cryopreservation protocols, cryopreservation of blood cells is no longer used on a large scale.
In the 1970s when no filter systems were available for the removal of leukocytes, cryopreservation followed by deglycerolization has been used for the removal of contaminating leukocytes from packed RBCs. The first more or less successful attempts to store platelets for prolonged time were done using DMSO as the cryoprotective agent. Human platelets frozen in DMSO can survive and function after transfusion. This cryopreservation method increases shelf-life to at least 1 year, but requires washing and processing to remove the DMSO which is not well tolerated by the human body. The accepted method for cryopreservation of platelets (if at all) uses DMSO at a concentration of $6 \%$ in the suspension to be frozen $[51,52]$.

\section{Freeze-Drying}

Much effort has been put in the invention of procedures that stabilize cells in the dried state at ambient temperatures [26]. Apart from drying, freeze-drying has become the standard method to remove bulk water from liquid samples. Freezedrying was used in World War II for preservation of blood plasma (which is cell-free) for use as a resuscitation fluid and restoration of coagulation deficiencies. Nowadays, freeze-drying has become a standard procedure for certain proteins. However, successful dehydration and rehydration of cells is much more complicated. In 1956, Klein and coworkers [53] reported on their results in testing the procoagulant properties of a freeze-dried preparation made from an extracted platelet suspension. Chemical fixation methods have also been used in attempts to stabilize cells during drying. Read et al. [54] applied a fixation with paraformaldehyde to enhance osmotic stability of platelets during freeze-drying. The ultrastructural integrity of these platelets looked as if preserved upon rehydration, and the platelets were reported as being capable of adhering to subendothelium and of spreading on an inert surface. Lyophilized fixed platelets have been shown to reduce the bleeding time in dogs on cardiopulmonary bypass [55]. A major disadvantage of this method is that paraformaldehyde irreversibly cross-links with membranes and proteins and therefore modifies platelets chemically. This modification is likely to impair proper functioning in hemostasis.

Recent attempts to freeze-dry mammalian cells have focused on the introduction of disaccharides into the cells. The use of nonreducing disaccharides such as trehalose and sucrose has been inspired by nature's way for the preservation of life in the anhydrobiotic state in some species [reviewed in 32]. Some anhydrobiotic organisms rely on accumulation of large quantities of disaccharides which, in combination with other protective compounds (i.e. LEA proteins, antioxidants), allow them to revive after rehydration. The major problem when using disaccharides for the lyopreservation of mammalian cells is to overcome the impermeability of cell membranes 


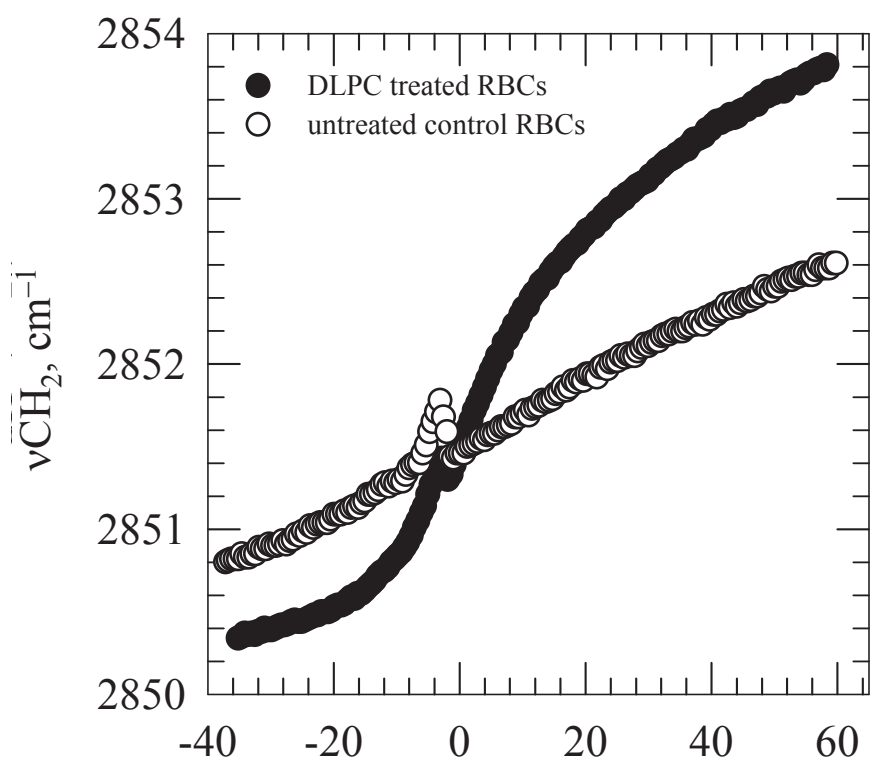

Temperature, ${ }^{\circ} \mathrm{C}$

Fig. 5. Membrane phase behavior of RBCs after incubation with DLPC liposomes. The data points reflect $\mathrm{vCH}_{2}$ versus temperature plots of nonliposome-treated RBCs (open circles) and liposome treated RBCs (filled circles). Data are adapted from [66].

to such disaccharides without disrupting the cellular structure. Guo et al. [56] have tackled this problem by expressing the genes that encode for trehalose-6-phosphate synthase and trehalose 6-phosphate phosphatase in human foreskin fibroblasts. They have shown that cells modified in this way are able to accumulate trehalose. However, the survival rates and longevity of these cells after drying were found to be rather poor. Another method proposed for the incorporation of trehalose into platelets is fluid phase endocytosis. Platelets have a relatively high surface-to-volume ratio compared to other cells, so they have been found to take up trehalose rapidly at $37^{\circ} \mathrm{C}$ by fluid phase endocytosis [57]. In vitro trehalose-loaded freeze-dried platelets have been shown to respond to various platelet agonists. Platelet recovery rates amount to approximately $90 \%$, and they were stable in the dried state. Subsequently, a procedure has been developed to freeze-dry whole platelet concentrates in specially designed lyophilization bags with one semipermeable site allowing water transport during freeze-drying [58]. However, as demonstrated by flow cytometric investigations, these platelets showed elevated levels of various platelet activation markers, which could be interpreted as a form of platelet damage. Recent activities focus on the use of freeze-dried platelets in topical wound healing [59], as in such preparations the platelets do not necessarily need to be viable.

One of the most frequently cited reports regarding the freeze-drying of RBCs is the one by Goodrich and co-workers
[60]. In this study a combination of glucose and HES was used to protect the cells. Rehydrated RBCs were shown to synthesize ATP and 2,3-DPG, and the activities of catalase and superoxide dismutase were preserved. However, this approach has been discontinued, and there is evidence that these RBCs were not truly 'dry', as only water contents at or below approximately $5 \%$ can be regarded as 'dry' under practical aspects. Additionally, the intactness of enzymes is sufficient for the explanation of some metabolic activities, but this is only one sine qua non (and not a sufficient one) for a viable cell. Later studies reported on the use of intracellular trehalose for freeze-drying of RBCs [61, 62]. In these studies in which RBCs were loaded with trehalose by an osmotic shock procedure to achieve intracellular lyoprotection, and recovery rates of about $55 \%$ have been reported. A follow-up study of this work [63] showed the synergistic effects of liposomes in combination with trehalose which will be elaborated on in the next section. Using this approach, increased recovey rates of about $70 \%$ could be achieved [63]. Despite the above mentioned efforts, neither freeze-dried RBCs nor freeze-dried platelets are presently used for patient treatment.

\section{Membrane Modification Strategies}

Since membranes are the primary site of biopreservation injury, efforts to modify cell membranes have been undertaken to improve the response of mammalian cells during cooling or drying. Membrane modification strategies rely on liposomes or cyclodextrin to add or extract cellular lipids and cholesterol. The stabilizing effect of liposomes on bull spermatozoa is known for some time [64]. Recently, liposomes have been investigated as protective agents for cryopreservation and freeze-drying of RBCs $[63,65]$. The effect of liposomes is considered to be due to lipid and cholesterol transfer between liposomes and cells. In a recent study, we have shown that liposomes extract cholesterol from RBC membranes [66]. In addition, lipid transfer from lipids inside of liposomes to RBC membranes was observed. Lipid and cholesterol transfer between liposomes and cells are dependent on the chemical lipid properties. Rapid lipid and cholesterol transfer is observed when RBCs are incubated with 1,2-dilauroyl-sn-glycero-3phosphocholine (DLPC), which has relatively short acyl chain lengths of $12 \mathrm{CH}_{2}$ groups. Treatment of RBCs with DLPC liposomes drastically affects the membrane phase behavior of RBC membranes (fig. 5). In contrast, 1,2-dipalmitoyl-snglycero-3-phosphocholine (DPPC) displays a much slower lipid and cholesterol exchange with RBCs. Depletion of cholesterol changes membrane properties. It causes an increase in lipid disorder, and it increases bilayer thickness [67, 68]. Alteration of the cell membrane cholesterol content can either enhance or decrease the low temperature response of cells [69]. In addition, liposomes influence the cell's permeability to membrane-permeating cryoprotectants. It could be shown 
that cholesterol-depleted cells have an increased permeability for glycerol [70].

For cryopreservation and freeze-drying, especially liposomes made from unsaturated lipids were shown to possess cryoprotective properties for RBCs. Kheirolomoom et al. [63] have speculated that liposomes may be able to repair transient membrane disruptions that occur during the stressful procedure of freezing and drying. The liposome technology is not yet ready for the hypothermic unfrozen storage of RBCs. There is evidence that liposomes composed of unsaturated lipids destabilize RBCs during hypothermic storage and cause increased hemolysis, whereas liposomes composed of certain saturated lipids possess stabilizing properties during hypothermic storage (Stadnick et al. unpublished results).
Interestingly, one of the advantages of liposomes is that lipids that have been shown to be effective stabilizers are usually natural, nontoxic phospholipids; therefore a removal after preservation is not necessary.

\section{Acknowledgement}

This work was financially supported by the German Research Foundation (Deutsche Forschungsgemeinschaft, DFG), Cluster of Excellence REBIRTH 'From regenerative biology to reconstructive therapy'

\section{Disclosure Statement}

The authors declared no conflict of interest.

\section{References}

$>_{1}$ Lion N, Crettaz D, Rubin O, Tissot JD: Stored red blood cells: a changing universe waiting for its map(s). J Proteomics 2010;73:374-385.

2 Greenwalt TJ: The how and why of exocytic vesicles. Transfusion 2006;46:143-152.

- Willekens FLA, Werre JM, Groenen-Dopp YAM, Roerdinkholder-Stoelwinder B, De Pauw B, Bosman GJ: Erythrocyte vesiculation: a self-protective mechanism? Br J Haematol 2008;141:549-556.

$\checkmark 4$ Rubin O, Crettaz D, Canellini G, Tissot JD, Lion $\mathrm{N}$ : Microparticles in stored red blood cells: an approach using flow cytometry and proteomic tools. Vox Sang 2008;95:289-297.

$\checkmark 5$ Kanias T, Acker JP: Biopreservation of red blood cells - the struggle with hemoglobin oxidation, FEBS J 2010;277:343-356.

6 Kriebardis AG, Antonelou MH, Stamoulis KE, Economou-Petersen E, Margaritis LH, Papassideri IS: Membrane protein carbonylation in nonleukodepleted CPDA-preserved red blood cells. Blood Cells Mol Dis 2006:36:279-282.

7 Kriebardis AG, Antonelou MH, Stamoulis KE, Economou-Petersen E, Margaritis LH, Papassideri IS: Storage-dependent remodeling of the red blood cell membrane is associated with increased immunoglobulin $\mathrm{G}$ binding, lipid raft rearrangement, and caspase activation. Transfusion 2007;47:1212-1220.

$>8$ Murphy S: Platelet storage for transfusion. Semin Hematol 1985;22:165-177.

9 Moroff G, Holme S: Concepts about current conditions for the preparation and storage of platelets. Transfusion Med Rev 1991;5:48-59.

$\checkmark 10$ Drobnis EZ, Crowe LM, Berger T, Anchordoguy TJ, Overstreet JW, Crowe JH: Cold shock damage is due to lipid phase transitions in cell membranes: a demonstration using sperm as a model. J Exp Zool 1993;265:432-437.

11 Arav A, Pearl M, Zeron Y: Does membrane lipid profile explain chilling sensitivity and membrane lipid phase transition of spermatozoa and oocytes? CryoLetters 2000;21:179-186.

12 Gousset K, Wolkers WF, Tsvetkova NM, Oliver AE, Field CL, Walker NJ, Crowe JH, Tablin F: Evidence for a physiological role for membrane rafts in human platelets. J Cell Physiol 2002;190:117-128.
13 Tablin F, Oliver AE, Walker NJ, Crowe LM, Crowe JH: Membrane phase transition of intact human platelets: correlation with cold-induced activation. J Cell Physiol 1996;168:305-313.

14 Tablin F, Wolkers WF, Walker NJ, Oliver AE, Tsvetkova NM, Gousset K, Crowe LM, Crowe JH: Membrane reorganization during chilling: implications for long-term stabilization of platelets. Cryobiology 2001;43:114-123.

15 Wolkers WF, Crowe LM, Tsvetkova NM, Tablin F, Crowe JH: In situ assessment of erythrocyte membrane properties during cold storage. Mol Membr Biol 2002;19:59-65.

16 Crowe JH, Carpenter JF, Crowe LM, Anchordoguy TJ: Are freezing and dehydration similar stress vectors? A comparison of modes of interaction of stabilizing solutes with biomolecules. Cryobiology 1990;27:219-231.

17 Crowe JH: Trehalose as a chemical chaperone: fact and fantasy. Adv Exp Med Biol 2007;595:143-158.

18 Wolkers WF, Balasubramanian SK, Ongstad EL, Bischof JC: Effects of freezing on membranes and proteins in $\mathrm{LNCaP}$ prostate tumor cells. Biochim Biophys Acta 2007;1768:728-736.

19 Balasubramanian SK, Wolkers WF, Bischof JC: Membrane hydration correlates to cellular biophysics during freezing in mammalian cells. Biochim Biophys Acta 2009;1788:945-953.

20 Mazur P: Freezing of living cells: mechanisms and implications. Am J Physiol 1984;247:C125-C142.

21 Mazur P: Kinetics of water loss from cells at subzero temperatures and the likelihood of intracellular freezing. J Gen Physiol 1963;47:347-369.

22 Toner M, Cravalho EG, Armant DR: Water transport and estimated transmembrane potential during freezing of mouse oocytes. J Membr Biol 1990; 115:261-272.

23 Levin RL, Cravalho EG, Huggins CE: A membrane model describing the effect of temperature on the water conductivity of erythrocyte membranes at subzero temperatures. Cryobiology 1976; 13:415-429.

24 Akhoondi M, Oldenhof H, Stoll C, Sieme H, Wolkers WF: Membrane hydraulic permeability changes during cooling of mammalian cells. Biochim Biophys Acta 2011;1808:642-648.
5 Rapatz G, Sullivan JJ, Luyet B: preservation of erythrocytes in blood containing various cryoprotective agents, frozen at various rates and brought to a given final temperature. Cryobiology 1968;5: 18-25.

26 Wolkers WF, Tablin F, Crowe JH: From anhydrobiosis to freeze-drying of eukaryotic cells. Comp Biochem Physiol 2002;131:535-543.

27 Carpenter JF, Crowe JH: An infrared spectroscopic study of the interactions of carbohydrates with dried proteins. Biochemistry 1989;28:3916-3922.

28 Prestrelski SJ, Tedeschi N, Arakawa T, Carpenter JF: Dehydration-induced conformational transitions in proteins and their inhibition by stabilizers. Biophys J 1993;65:661-671.

29 Dong A, Prestrelski SJ, Allison SD, Carpenter JF: Infrared spectroscopic studies of lyophilizationand temperature-induced protein aggregation. $\mathbf{J}$ Pharm Sci 1995;84:415-424.

30 Carpenter JF, Martin B, Crowe LM, Crowe JH: Stabilization of phosphofructokinase during air drying with sugars and sugarytransition metal mixtures. Cryobiology 1987;24:455-464.

31 Crowe JH, Hoekstra FA, Crowe LM: Anhydrobiosis. Annu Rev Physiol 1992:54:579-599.

32 Crowe JH, Crowe LM, Carpenter JF, Prestrelski SJ, Hoekstra FA: Anhydrobiosis: cellular adaptations to extreme dehydration; in Dantzler WH (ed): Comparative Physiology, Handbook of Physiology, Vol. II. Oxford, Oxford University Press, 1997 pp 1445-1477.

33 Arakawa T, Timasheff SN: Preferential interactions of proteins with solvent components in aqueous amino acid solutions. Arch Biochem Biophys 1983; 224:169-177.

34 Arakawa T, Timasheff SN: The stabilization of proteins by osmolytes. Biophys J 1985;47:411-414.

35 Galinski EA: Osmoadaptation in bacteria. Adv Microb Physiol 1995;37:272-328.

36 Arakawa T, Timasheff SN: Stabilization of protein structure by sugars. Biochemistry 1982;21:6536-6544.

37 Westh P: Unilamellar DMPC vesicles in aqueous glycerol: preferential interactions and thermochemistry. Biophys J 2003;84:341-349. 
>38 Oldenhof H, Friedel K, Sieme H, Glasmacher B, Wolkers WF: Membrane permeability parameters for freezing of stallion sperm as determined by Fourier transform infrared spectroscopy. Cryobiology 2010;61:115-122.

39 Tullis JL, Gibson JG, Sproul MT, Tinch RJ, Baudanze P: Advantages of the high glycerol mechanical systems for red cell preservation: a 10-year study of stability and yield; in Spielmann W, Seid S (eds): Modern Problems of Blood Preservation. Stuttgart, Fischer, 1970, pp 161-167.

40 Iijima T: Thermal analysis of cryoprotective solutions for red blood cells. Cryobiology 1998;36:165173.

41 Cottone G, Ciccotti G, Cordone L: Protein-trehalose-water structures in trehalose coated carboxymyoglobin. J Cell Physiol 2002;117:9862-9866.

42 Lins RD, Pereira CS, Hunenberger PH: Trehaloseprotein interactions in aqueous solutions, Proteins 2004;55:177-186.

43 Wolkers WF, Oldenhof H, Glasmacher B: Effect of trehalose on dehydration kinetics of phospholipid vesicles, as measured in real time using ATR infrared spectroscopy. Cryobiology 2010;61:108-114.

44 Sun WQ, Davidson P, Chan HS: Protein stability in the amorphous carbohydrate matrix: relevance to anhydrobiosis. Biochim Biophys Acta 1998;1425: 245-254.

45 Slade L, Levine H: A food polymer science approach to structure property relationships in aqueous food systems: Non-equilibrium behavior of carbohydrate-water systems; in Levine H, Slade L (eds): Water Relationships in Food. New York, Plenum Press, 1991, pp 29-101.

46 Li S, Patapoff TW, Overcashier D, Hsu C, Nguyen TH, Borchardt RT: Effects of reducing sugars on the chemical stability of human relaxin in the lyophilized state. J Pharm Sci 1996;85:873-877.

47 Rowe AW, Eyster E, Kellner A: Liquid nitrogen preservation of red blood cells for transfusion: a low glycerol-rapid freeze procedure. Cryobiology 1968;5:119-128.

48 Sputtek A, Singbartl G, Langer R, Schleinzer W, Henrich HA, Kühnl P: Cryopreservation of red blood cells with the non-penetrating cryoprotectant hydroxyethyl starch. CryoLetters 1995;16:283-288.
49 Horn EP, Sputtek A, Standl T, Rudolf B, Kühnl P, Schulte am Esch J: Transfusion of autologous, hydroxyethyl starch-cryopreserved red blood cells. Anesth Analg 1997;85:739-745.

50 Sputtek A: Cryopreservation of red blood cells and platelets. Methods Mol Biol 2007;368:283-301.

51 Valeri CR, Feingold $\mathrm{H}$ and Marchionni LD: A simple method for freezing human platelets using $6 \%$ dimethylsulfoxide and storage at $-80^{\circ} \mathrm{C}$. Blood 1974;43:131-136.

52 Bock M, Schleuning M, Heim MU, Wemperl W: Cryopreservation of human platelets with dimethylsulfoxide: changes in biochemistry and cell function. Transfusion 1995;35:921-924.

53 Klein E, Sarbar S, Djerassi I, Toch R, Freeman G, Arnold P: The preparation and clinical administration of lyophilized platelet material to children with acute leukemia and aplastic anemia. J Pediatr 1956;49:517-522.

54 Read MS, Reddick RL, Bode AP, Bellinger DA, Nichols TC, Taylor K, Smith SV, McMahon DK, Griggs TR, Brinkhous KM: Preservation of hemostatic and structural properties of rehydrated lyophilized platelets: potential for long-term storage of dried platelets for transfusion. Proc Natl Acad Sci U S A 1995;92:397-401.

55 Bode AP, Lust RM, Read MS, Fischer TH: Correction of the bleeding time with lyophilized platelet infusions in dogs on cardiopulmonary bypass. Clin Appl Thromb Hemost 2008;14:38-54.

56 Guo N, Puhlev I, Brown DR, Mansbridge J, Levine F: Trehalose expression confers desiccation tolerance on human cells. Nat Biotechnol 2000;18:168-171.

57 Wolkers WF, Walker NJ, Tablin F, Crowe JH: Human platelets loaded with trehalose survive freeze-drying. Cryobiology 2001:42:79-87.

58 Wolkers WF, Walker NJ, Tamari Y, Tablin F, Crowe JH: Towards a clinical application of freezedried human platelets. Cell Preserv Technol 2003;1: 173-186.

59 Sum R, Hager S, Pietramaggiori G, Orgill DP, Dee J, Rudolph A, Orser C, Fitzpatrick GM, Ho D: Wound-healing properties of trehalose-stabilized freeze-dried outdated platelets. Transfusion 2007; 47:672-679.
60 Goodrich RP, Sowemimo-Coker SO, Zerez CR, Tanaka KR: Preservation of metabolic activity in lyophilized human erythrocytes. Proc Natl Acad Sci U S A 1992;89:967-971

61 Satpathy GR, Török Z, Bali R, Dwyre DM, Little E, Walker NJ, Tablin F, Crowe JH, Tsvetkova NM: Loading red blood cells with trehalose: a step towards biostabilization. Cryobiology 2004;49; 123-136.

62 Török Z, Sapathy GR, Banerjee M, Bali R, Little E, Novaes R, Van Ly H, Dwyre DM, Kheirolomoom A, Tablin F, Crowe JH, and Tsvetkova NM: Preservation of trehalose-loaded red blood cells by lyophilization. Cell Preserv Technol 2005;3:96-111.

63 Kheirolomoom A, Satpathy GR, Török Z, Banerjee M, Bali R, Novaes RC, Little E, Manning DM, Dwyre DM, Tablin F, Crowe JH, Tsvetkova NM: Phospholipid vesicles increase the survival of freeze-dried human red blood cells. Cryobiology 2005:51:290-305.

64 Graham JK, Foote RH: Effect of several lipids, fatty acyl chain length, and degree of unsaturation on the motility of bull spermatozoa after cold shock and freezing. Cryobiology 1987;24:42-52.

65 Holovati JL, Gyongyossy-Issa M, Acker JP: Effects of trehalose-loaded liposomes on red blood cell response to freezing and post-thaw membrane quality. Cryobiology 2008;58:75-83.

66 Stoll C, Stadnick H, Kollas O, Holovati JL, Glasmacher B, Acker JP, Wolkers WF: Liposomes alter thermal phase behavior of red blood cell membranes. Biochim Biophys Acta 2011;1808:474-481.

67 Levine YK, Wilkins MHF: Structure of oriented lipid bilayers. Nat New Biol 1971;230: 69-72.

68 McIntosh TJ: The effect of cholesterol on the structure of phosphatidylcholine bilayers. Biochim Biophys Acta 1978;513:43-58.

69 Moore AI, Squires EL, Graham JK: Adding cholesterol to the stallion sperm plasma membrane improves cryosurvival. Cryobiology 2005;51:241-249.

70 Bruckdorfer KR, Demel RA, de Gier J, van Deenen LLM: The effect of partial replacements of membrane cholesterol by other steroids on the osmotic fragility and glycerol permeability of other erythrocates. Biochim Biophys Acta 1989;183:334-345.

71 Wolkers WF: Biomedical FTIR spectroscopy of lipids; in Barth A, Haris PI (eds): Biological and Biomedical Infrared Spectroscopy. Amsterdam, IOS Press, 2009, pp 272-287. 